Brazilian Journal

of Chemical

Engineering

\title{
COMPARISON BETWEEN EXPERIMENTAL AND SIMULATED RESULTS OF BIODIESEL PRODUCTION BY REACTIVE DISTILLATION AND ENERGETIC ASSESSMENT
}

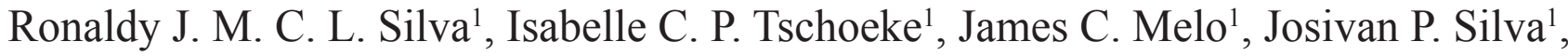 \\ Jose G. A. Pacheco ${ }^{1}$, José M. F. Silva ${ }^{1}$ and Thibério P. C. Souza ${ }^{1 *}$ \\ ${ }^{1}$ Universidade Federal de Pernambuco, Departamento de Engenharia Química, Laboratório de Processos Químicos \\ e Simulação Dinâmica, Recife, PE, Brasil. ORCID: 0000-0002-2565-2027; ORCID: 0000-0002-0958-4386; \\ ORCID: 0000-0002-7325-8403; ORCID: 0000-0003-3294-9352; ORCID: 0000-0002-8812-5021; ORCID: 0000-0002-6407-8793; \\ E-mail: thiberio_souza@hotmail.com, ORCID: 0000-0001-9452-948X
}

(Submitted: May 19, 2017 ; Revised: January 31, 2018 ; Accepted: March 25, 2018)

\begin{abstract}
Biodiesel appears to be a likely substitute to conventional diesel. However, the main challenge has been the creation of a competitive advantage for the biodiesel production process in terms of innovation and efficiency. The reactive distillation technique for biodiesel production is possibly a key force to overcome this technological issue because it combines chemical reaction and the separation process inside the same unit. This work presents kinetic data for biodiesel production via the ethylic route and compare them with the methylic one. It also compares experimental results in a $1.5 \mathrm{~m}$ reactive distillation pilot plant with simulated ones in ASPEN PLUS for ethylic biodiesel production with a molar ratio 6/1 (alcohol/oil). Kinetic parameters obtained for the ethylic study were $\mathrm{k}_{\mathrm{o}}=8173 \mathrm{dm}^{3} /(\mathrm{mol} . \mathrm{min})$ and $\mathrm{E}_{\mathrm{a}}=27.48 \mathrm{~kJ} / \mathrm{mol}$. Indeed, at the bottom of a six stage column overall the ethylic and methylic biodiesel accounted for $60.1 \%$ and $67.8 \%$, respectively. Following this, a sensitivity analysis considering 20 stages of equilibrium showed an ester conversion above $97 \%$. The total energy required to produce biodiesel via a conventional batch reactor was $1210 \mathrm{~W} / \mathrm{h}$ for the ethylic route and $2430 \mathrm{~W} / \mathrm{h}$ for methylic one, while it amounted to approximately $1000 \mathrm{~W} / \mathrm{h}$ for both routes in the reactive distillation process. Keywords: Biodiesel; Reactive distillation; Ethanol; Experimental data; ASPEN PLUS.
\end{abstract}

\section{INTRODUCTION}

Energy security is a main issue among environmental global politics. This is mainly due to the fact that the need for clean and renewable sources that can mitigate the harmful effects caused by greenhouse gases, besides being economically viable, is a crucial challenge. The production of diesel from diesel fuel will be jeopardized, since this non-renewable source will become increasingly scarce due to oil shortages. As a result, an alternative for replacing fossil fuel diesel is the use of biodiesel obtained from atransesterification reaction (Aranda et al., 2009; Jain et al., 2012; Yang et al., 2012).
Indeed, this ecologically friendly biofuel is considered to be sustainable because it has a closed carbon cycle and it also does not add a significant carbon fingerprint to the atmosphere compared with diesel fuels. Other advantages of using biodiesel over diesel include job generation in the primary sector and the fact that it does not require modification of conventional diesel cycle engines (Choedkiatsakul et al., 2014; Yuste et al., 2006).

The main technical barrier is to develop a profitable biodiesel production process. The high cost of raw materials and subsequent unit operations required to purify this renewable fuel have led many investors to

\footnotetext{
* Corresponding author: Thibério P. C. Souza - E-mail: thiberio_souza@hotmail.com
} 
avoid it. In Brazil, for example, approximately $80 \%$ of the vegetable oil used in the biodiesel mixture is from soybean oil. Considering the fact that soybean is a food commodity, its price has globally increased due to food security global policy. Furthermore, there has been an urge for alternative vegetable oils, such as cottonseed, canola and castor oil (Festel, 2008; Vogel et al., 2008).

Although a batch reactor process for biodiesel production is a well disseminated and mature technology, it is adequate only for low production needs. This is because among its main disadvantage is the high cost when it comes to large-scale production, since each reaction cycle needs approximately one hour reaction time. Furthermore, in order to make biodiesel economically viable it is crucial to reduce the industrial production cost (Boon-anuwat et al., 2015; Zhang et al., 2003). Most biodiesel studies are based on bench scale alkali-catalyzed technology and no detailed kinetic and equipment sizing data are available to compare experimental results with process simulation (Machado et al., 2013; Chang and Liu 2010).

Zhang et al. (2008) simulated an alkali-catalyzed continuous biodiesel production by using triolein to represent canola vegetable oil with NRTL and UNIQUAC thermodynamic models for high non-polar liquid components. Results of economic assessment indicated that the raw material expenses accounted for a major portion of the total manufacturing cost. Glycerin is also a valuable by-product, which could be used to reduce up to $10 \%$ of the total manufacturing cost and the plant capacity is reported in the literature to be a key factor in terms of economic feasibility of the process (Qian et al., 2008; Rashid et al., 2009).

The sugar cane produced in Brazil has a major contribution for the country, since it is expected that by 2020 the total impact on its economy will be approximately $\$ 231$ billion on total output, $\$ 131$ billion on the gross domestic product and $\$ 37.5$ billion in remuneration to employees (Costa and Guilhoto, 2011). Therefore, the possibility of producing biodiesel from ethanol is in line with the country's natural energetic sources. The majority of studies of biodiesel production use methanol to carry out the transesterification reaction due to its higher reactivity over ethanol (Souza et al., 2014). However, the main disadvantages of using methanol include its high level of toxicicity and the necessity to be imported in Brazil in order to supply the local economy (Kapilakarn and Peugtong, 2007; Souza et al., 2014). Furthemore, the comparison between ethanol and methanol as an option of the alcohol for biodiesel production poses a key factor in order to evaluate the potencial to produce this renewable fuel from sugar cane.

The use of cottonseed oil instead of virgin soybean oil to produce biodiesel is an alternative way to reduce feedstock cost because it is a by-product of the cotton industry. The cottonseed accounts for $60 \%$ of the plant while $40 \%$ is the fiber used in the textile industry for manufacturing (Kiss, 2011). Another way to produce biodiesel is by reactive distillation, which is a very recent technology when applied to biodiesel production. In recent years, reactive distillation has shown advantages for the biodiesel production process when compared to the conventional batch reactors. Among them are reduced reaction time and separation units. (He et al., 2006; Kapilakarn and Peugtong, 2007).

The reactive distillation technology applied to biodiesel production is especially attractive because it significantly reduces the volumetric flow of alcohol, which is vaporized at the bottom of the column. This is possible because it is continuously recycled at the top of the column (Souza et al., 2014; Boon-anuwat et al., 2015). Biodiesel is generated throughout the column due to a counter current flow between oil moving downwardly and the alcohol flowing upwardly. This technique can also process a significant amount of raw material in a short time interval as a continuous process (Boon-anuwat et al., 2015).

In terms of economic viability, a number of authors have highlighted that reactive distillation is potentially low cost. Gomez-Castro et al. (2010) simulated a modified thermally coupled reactive distillation and concluded that this system can be designed to reduce the energy consumption of biodiesel production at high pressures. Machado et al. (2013) pointed out that one of the major advantages of this technique is the energy saving during the reboiler operation, which is crucial for obtaining high quality esters. Souza et al. (2014) concluded that reactive distillation is more economic than a conventional batch process, especially in terms of raw materials usage.

This work aimed to compare simulated and experimental results for biodiesel production by reactive distillation based on the methylic and ethylic routes. All simulations were carried out in ASPEN PLUS by considering kinetic parameters that were obtained experimentally and from the literature. Following this, a sensitivity analysis considering a 20 stages column was performed in Aspen Plus in order to estimate ester conversion. It also compared the energy comsumption of biodiesel production, which was experimentally obtained, between a convencional batch reactor and reactive distillation for both routes.

\section{MATERIALS AND METHODS}

\section{Characterization of Components}

It was necessary to select the main components of the vegetable oil feedstock before performing the process simulation. A GC-Master gas chromatograph 
with flame ionization detector and a capillary carbowax column was the equipment used to determine vegetable oil composition based on the triacylglycerol composition of degummed cottonseed oil. Chemical components for simulation in ASPEN PLUS software do not contain all existing compounds in cottonseed oil. However, it allows the insertion of new compounds in its library. Table 1 shows the chemical compounds created for this process simulation.

Table 1. Chemical compounds created for simulating cotton seed oil composition.

\begin{tabular}{|c|c|c|}
\hline Component & $\begin{array}{c}\text { Chemical } \\
\text { formula }\end{array}$ & $\begin{array}{c}\text { Molecular } \\
\text { weight }\end{array}$ \\
\hline 9-Octadecenoic triglyceride (oleic) & $\mathrm{C}_{57} \mathrm{H}_{104} \mathrm{O}_{6}$ & 885.43 \\
\hline $\begin{array}{l}\text { 9,12-Octadecadienoic triglyceride } \\
\text { (linoleic) }\end{array}$ & $\mathrm{C}_{57} \mathrm{H}_{98} \mathrm{O}_{6}$ & 879.38 \\
\hline $\begin{array}{l}\text { Hexadecanoic acid triglyceride } \\
\text { (palmitic) }\end{array}$ & $\mathrm{C}_{51} \mathrm{H}_{98} \mathrm{O}_{6}$ & 807.32 \\
\hline Octadecanoic triglyceride (stearic) & $\mathrm{C}_{57} \mathrm{H}_{106} \mathrm{O}_{6}$ & 887.43 \\
\hline $\begin{array}{l}\text { 9-Octadecenoic acid, methyl ester } \\
\text { (oleic) }\end{array}$ & $\mathrm{C}_{19} \mathrm{H}_{36} \mathrm{O}_{2}$ & 296.48 \\
\hline $\begin{array}{l}\text { 9,12-Octadecadienoic methyl ester } \\
\text { (linoleic) }\end{array}$ & $\mathrm{C}_{19} \mathrm{H}_{34} \mathrm{O}_{2}$ & 294.47 \\
\hline $\begin{array}{l}\text { Hexadecanoic acid methyl ester } \\
\text { (palmitic) }\end{array}$ & $\mathrm{C}_{17} \mathrm{H}_{34} \mathrm{O}_{2}$ & 270.45 \\
\hline $\begin{array}{l}\text { Octadecanoic acid, methyl ester } \\
\text { (stearic) }\end{array}$ & $\mathrm{C}_{19} \mathrm{H}_{38} \mathrm{O}_{2}$ & 298.50 \\
\hline
\end{tabular}

\section{Kinetic Model for the Methylic and Ethylic Routes}

For the cottonseed oil methylic transesterification reaction a pseudo-homogeneous kinetic model was considered (Santana et al., 2010; Perlingeiro, 2005). Kinetic parameters were estimated from experiments carried out in a $1 \mathrm{~L}$ stirred batch reactor at 40, 50 and 60 ${ }^{\circ} \mathrm{C}$. The methanol/cottonseed oil molar ratio was $6 / 1$ and $\mathrm{NaOH}$ catalyst concentration was $1 \%(\mathrm{~m} / \mathrm{m})$ of vegetable oil mass. All samples, collected after each 5 min of reaction time, were purified and analyzed by gas chromatography.

The kinetic model parameters for the ethylic route were obtained by a bench study, following a methodology proposed by Melo et al., (2007). An experimental planning was elaborated to obtain a first order ethylic kinetics for transesterification that was adjusted by multiple non-linear regression in MATLAB software using the FIT function (Constantinedes and Mostoufi, 2000). It allowed determination of the global constant value without linearization. The kinetic model used is presented in Eqs. 1, 2 and 3.

$$
\begin{aligned}
& \frac{\mathrm{dCtg}}{\mathrm{dt}}=-\mathrm{k} \cdot \mathrm{Ctg} \cdot \mathrm{Ca} \\
& \mathrm{Ca}=\mathrm{Cao}-3 \cdot(\mathrm{Ctgo}-\mathrm{Ctg}) \\
& \mathrm{k}=\mathrm{ko} \cdot \exp \left(-\frac{\mathrm{Ea}}{\mathrm{R} \cdot \mathrm{T}}\right)
\end{aligned}
$$

where $\mathrm{C}_{\mathrm{tg}}$ is the triacylglycerol concentration; $\mathrm{C}_{\mathrm{a}}$ is the concentration of alcohol; $\mathrm{C}_{\text {ao }}$ and $\mathrm{C}_{\mathrm{tgo}}$ are initial feed concentrations; $\mathrm{k}$ is the kinetic constant; $\mathrm{k}_{\mathrm{o}}$ is the frequency factor of the reaction rate; $\mathrm{E}_{\mathrm{a}}$ is the activation energy and $\mathrm{T}$ is the temperature.

\section{Thermodynamic Model Approach}

The group contribution method modified UNIFACDo (Dortmund) has been reported by a number of researchers to be adequate for a wide range of simulations. This is because it provides reliable results and comprises a significant range of applicability for solid-liquid equilibria, vapor-liquid equilibria, activity coefficients at infinite dilution, azeotropic data, and excess enthalpies (Gmehling et al., 2002; Kuramochi et al., 2009; Muhammad et al., 2017). Muhammad et al. (2017) stated that, for biodiesel modeling purposes, the UNIFAC-Do usually provides good results because the deviations in terms of temperature and vapor compositions are lower than $1.0 \mathrm{~K}$ and 0.020 , respectively. Furthermore, the UNIFAC-Do was considered to represent adequately the liquid-vapor equilibrium in this study of the biodiesel production process.

\section{Reactive Distillation Column Process Simulation and Operation}

Before starting the experimental analysis, a simulation was performed inside the reactive distillation colunm by using ASPEN PLUS. This simulation aimed to obtain project parameters and optimal processing conditions. It was then possible to save reactants, money and time required to conduct the experimental study. Simulation followed the operating conditions of Table 2 and the experimental planning shown in Table 3, which included oil/alcohool molar ratio, refllux ratio and temperature at the bottom of the column. This experimental planning was used for both the ethylic and methylic routes.

Reflux ratio of $0.1 \%$ refers to the column operating without reflux at the top and a reflux ratio of $100 \%$ refers to the column operating with all alcohool excess returning to the process. In order to meet process

Table 2. Operational data for biodiesel production simulation from cottonseed oil by reactive distillation.

\begin{tabular}{lc}
\hline \multicolumn{1}{c}{ Variable } & Value \\
\hline Oil feed flow rate & $43.2 \mathrm{~L} / \mathrm{h}$ \\
Oil temperature & $50^{\circ} \mathrm{C}$ \\
Oil pressure & $1 \mathrm{~atm}$ \\
Mass fraction of oleic triglyceride & 0.2412 \\
Mass fraction of palmitic triglyceride & 0.1375 \\
Mass fraction of linoleic triglyceride & 0.5755 \\
Mass fraction of stearic triglyceride & 0.0458 \\
Alcohol feed flow rate & $31.1 \mathrm{~L} / \mathrm{h}$ \\
Temperature of alcohol & $100^{\circ} \mathrm{C}$ \\
Alcohol pressure & $1 \mathrm{~atm}$ \\
Number of Trays & 6 \\
\hline
\end{tabular}


Table 3. Experimental planning carried out for simulation in ASPEN PLUS.

\begin{tabular}{ccc}
\hline Parameter & Level (-1) & Level (+1) \\
\hline Molar Ratio & $4 / 1$ & $6 / 1$ \\
Reflux Ratio & $0.1 \%$ & $100 \%$ \\
Temperature & $60^{\circ} \mathrm{C}$ & $75^{\circ} \mathrm{C}$ \\
\hline
\end{tabular}

simulation requirements in ASPEN PLUS, it was necessery to adopt $0.1 \%$ for the condition without reflux, since this simulator does not accept lower values.

For the experimental study a glass reactive distillation column was built with one oil feeding point, one alcohol feeding point and six sampling points along the distillation column, a reflux system at the top and a total condenser. A catalyst dosing system with three concentration levels, reboiler, pumping system for reactants and cooling water, volumetric flow meter system and regulator valve to establish the molar ratio between alcohol and oil were also integrated to the column. The reactive distillation column was 1.5 meter tall and $3 \mathrm{~cm}$ in diameter. It was packed with rashing rings of $7 \mathrm{~mm}$ in diameter. Simulation conditions in ASPEN PLUS ${ }^{\circledR}$ were determined to represent the experimental process on a laboratorial scale. Fig. 1 represents the process flowsheet used to perform the experimental and simulation study.

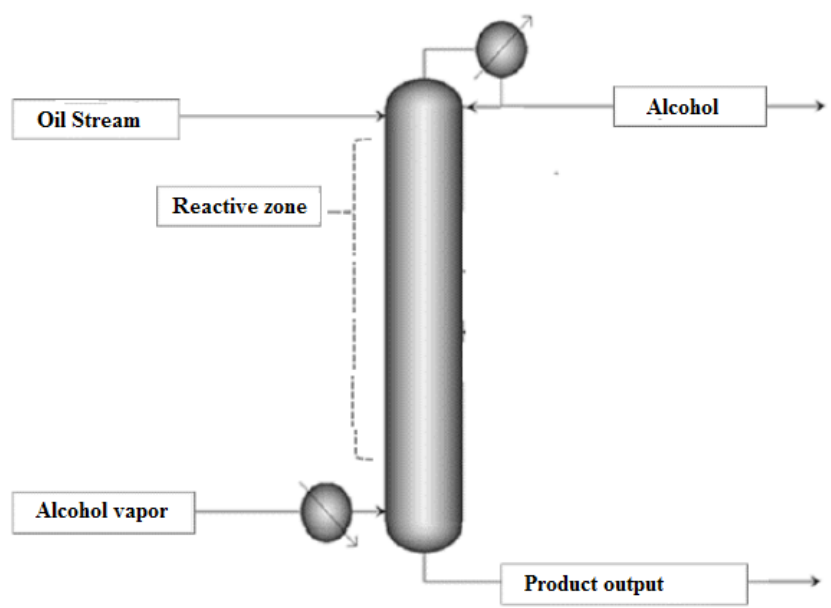

Figure 1. Process flowsheet adopted for the simulation and experimental reactive distillation plant with condensed reflux and catalyst dosage system highlighted.

\section{Operational Conditions of the Reactive Distillation Column}

Based on simulated results the initial experimental tests in the reactive distillation column were performed according to the operating parameters established in ASPEN PLUS. Oil was initially heated up to $50^{\circ} \mathrm{C}$ before being pumped to the top column stage. Volumetric flow rates of feeding oil and ethyl alcohol were $43.2 \mathrm{~L} / \mathrm{h}$ and $31.1 \mathrm{~L} / \mathrm{h}$, respectively, which provided a molar ratio of $6 / 1$ (alcohol/oil). Before entering the bottom of the column the alcohol stream was totally vaporized after passing through the reboiler. The average temperature of the column was $75^{\circ} \mathrm{C}$ and the final product was obtained at the bottom.

Ester and glycerol were generated by the transesterification reaction due to a counter current flow between the ascending vapor of alcohol and the descending flow of oil and condensed ethyl alcohol. The excess of alcohol used in the process is condensed, and returns at the top via the reflux stream, which receives the catalyst. The catalyst was added at the top of the column and followed a downwardly flow, which aimed to promote a good operating condition. The amount added was $1 \%(\mathrm{~m} / \mathrm{m})$ of catalyst/oil. $\mathrm{NaOH}$ in alcoholic solution generates sodium ethoxide, which has the primary function to reduce the activation energy, accelerating the chemical reaction. Catalyst level variations will be considered in further studies. The pilot plant for the reactive distillation process is shown in Fig. 2 with the oil and vaporized alcohol entering at the top and at the bottom of column, respectively. Alcohol vapor provides the energy necessary to heat the process, which is required by the transesterification reaction. The reactive distillation column had collecting sections spaced at $0.25 \mathrm{~m}$, accounting for six sampling points.

Excess alcohol is condensed at the top of the column, receiving the $\mathrm{NaOH}$ catalyst that returns to the process as a reflux stream. Rashing rings were used not only to pack the reactive distillation column but also as a solid catalyst in the reaction zone (metallic copper).

After the column reached the stationary state, a variety of samples was collected along the 6 sampling points, intending to evaluate ester conversion from the top-down.

\section{Experimental and Simulated Ester Determination}

Ester conversion was determined following EN 14103 (2011) by using a Shimadzu GC-Master gas chromatograph equiped with a flame ionization detector and a capillary carbowax column. Sulfuric acid was added to the samples in order to stop the transesterification reaction. After a neutral washing and centrifugation at $8000 \mathrm{rpm}$, the resulting salts were separated from biodiesel. Finally, all samples were centrifuged and dried at $120^{\circ} \mathrm{C}$ for four hours.

Ester simulated conversion in ASPEN Plus was calculated based on Eq.4

$$
\% \text { Ester }=\frac{\left(\mathrm{F}_{\mathrm{tgo}}-\mathrm{F}_{\mathrm{tg}}\right)}{\mathrm{F}_{\mathrm{tgo}}} 100
$$

in which \% Ester, $\mathrm{F}_{\mathrm{tgo}}$ and $\mathrm{F}_{\mathrm{tg}}$ are Ester conversion percent, inicial and final mass flow rate of triglyceride 


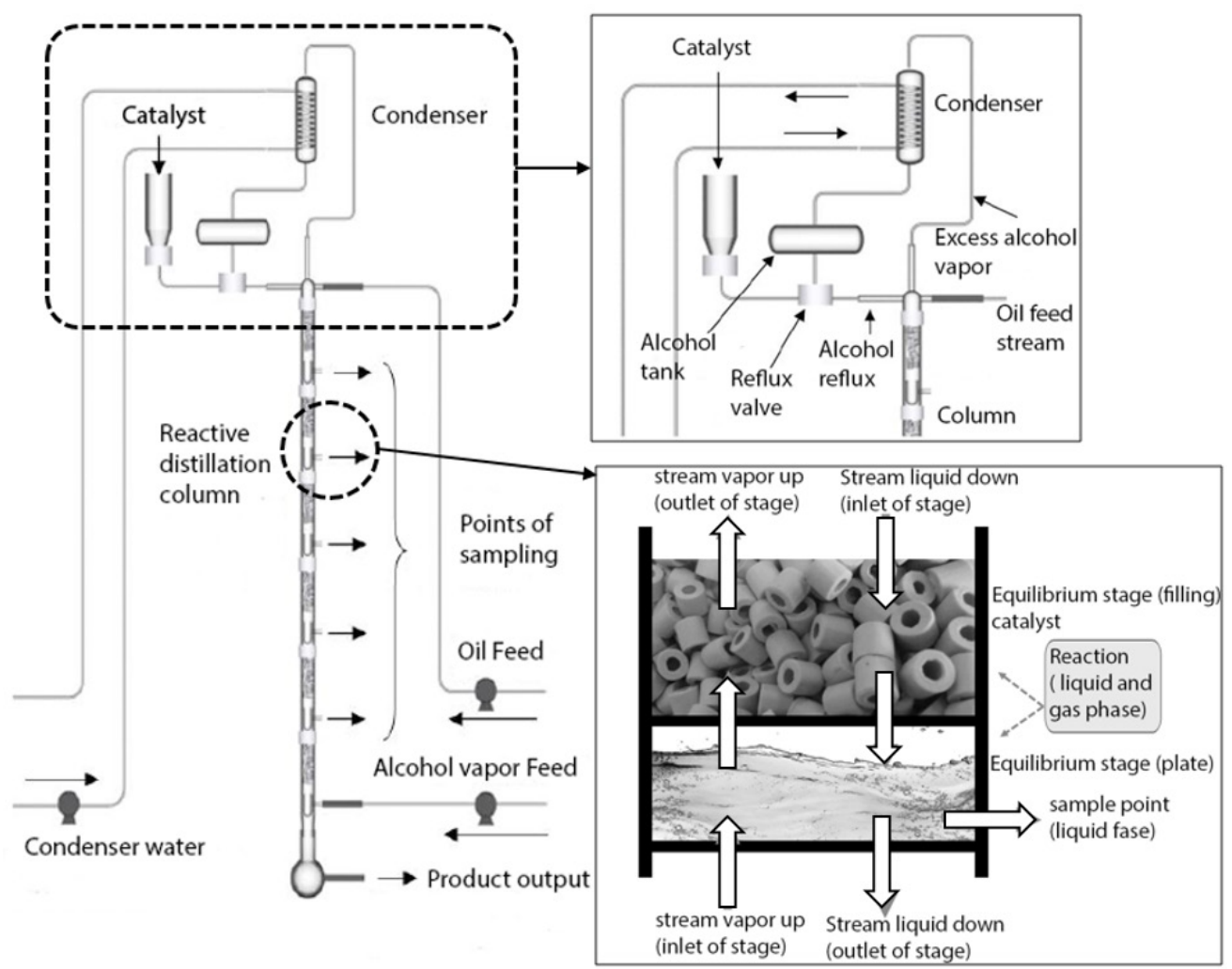

Figure 2. Reactive distillation column for biodiesel production.

concentration in $\mathrm{Kg} / \mathrm{h}$. These simulated data were obtained from the ASPEN Plus results interface.

\section{Energy Assesment of the Biodiesel Production Process}

The reactive distillation column used in this work included a powerconsumption controlling and monitoring system. Furthermore, a hardware supervisory system was developed in 3ds Max software for communication between column and computer. This supervisory system controlled the volumetric flow rate of oil and alcohol feeding the column and the reflux valve of condensed liquid at the top of the column. Indeed, it was possible to create a process operation report, including electrical energy consumption in real time due to temperature, pressure and liquid level sensors that were attached to the column. Dosage level of the catalyst in the process and the temperature at the top and base of column could also be specified via software.

The energy consumption for the conventional bacth process was obtained with a stirried tank reactor of the Strategic Technologies Center of Northeast CETENE, which uses cotton seed oil as raw material and also has inline sensors that indicated the power consumption of the industrial plant. It was intended to conduct both processes with the same operating conditions.

\section{RESULTS AND DISCUSSION}

The kinetic parameters frequency factor and activation energy were $\mathrm{ko}=8173 \mathrm{dm}^{3} /(\mathrm{mol} . \mathrm{min})$ and
$\mathrm{E}_{\mathrm{a}}=27.48 \mathrm{~kJ} / \mathrm{mol}$, for the ethylic study. These results are the same order of magnitude reported by Melo et al. (2007) for the methylic route, being $E_{a}=29.3$ $\mathrm{kJ} / \mathrm{mol}$ and frequency factor $\mathrm{k}_{0}=3320 \mathrm{dm}^{3} /(\mathrm{mol}$. min). Based on these data it was possible to insert the kinetic models in ASPEN PLUS software to perform simulations.

Although the kinetic parameters of the transesterification reaction were not the main focus of this work, they were obtained by experiment in order to correctly perform all simulations in ASPEN PLUS.

It was possible to observe, due to simulated results, that a chemical reaction was verified along the column, varying from oil feeding point, which is located at the top, down to the collecting point at the bottom. Initially, alcohol was fed in the vapor phase at the bottom of the column. After condensed liquid was recognized at the top, the catalyst $(\mathrm{NaOH})$ was released.

The total operating time was 20 minutes, indicating that for a process operating with a reactive distillation column, biodiesel production becomes 3 times faster than with conventional batch reactors. Another relevant fator was the low level of catalyst used in this

Table 4. Comparison between methylic and ethylic route.

\begin{tabular}{lcc}
\hline \multicolumn{1}{c}{ Results for considered routes } & $\begin{array}{c}\mathbf{k}_{\mathbf{0}} \\
\left(\mathbf{m i n}^{-1}\right)\end{array}$ & $\begin{array}{c}\text { Ea } \\
(\mathbf{J} / \mathbf{m o l})\end{array}$ \\
\hline Ethylic kinetics & 8173 & 27480 \\
Methylic kinetics (Melo et al., 2013) & 3320 & 29300 \\
\hline
\end{tabular}


process. This is because high $\mathrm{NaOH}$ concentrations, above $5 \%(\mathrm{~m} / \mathrm{m})$, can lead to saponification reactions. Furthermore, the aspect of achieving ester conversion with low rates of catalyst shows another advantage of the biodiesel production process by reactive distillation

Ester conversion experimental and simulated results can be seen in Table 5 and its graphical representation in Fig. 3.

It can be noted immediately that there was a reaction rate at the beginning of the column, accounting for $10.1 \%$ in ester for the transesterification reaction carried out with methanol. In the following stages it is possible to see that reaction continues to occur, reaching 67.8 at the bottom of column. It can be noted in Fig. 3 that the simulation curves obtained in ASPEN PLUS ${ }^{\circledR}$ for both methylic and ethylic biodiesel are in line with the experimental results.

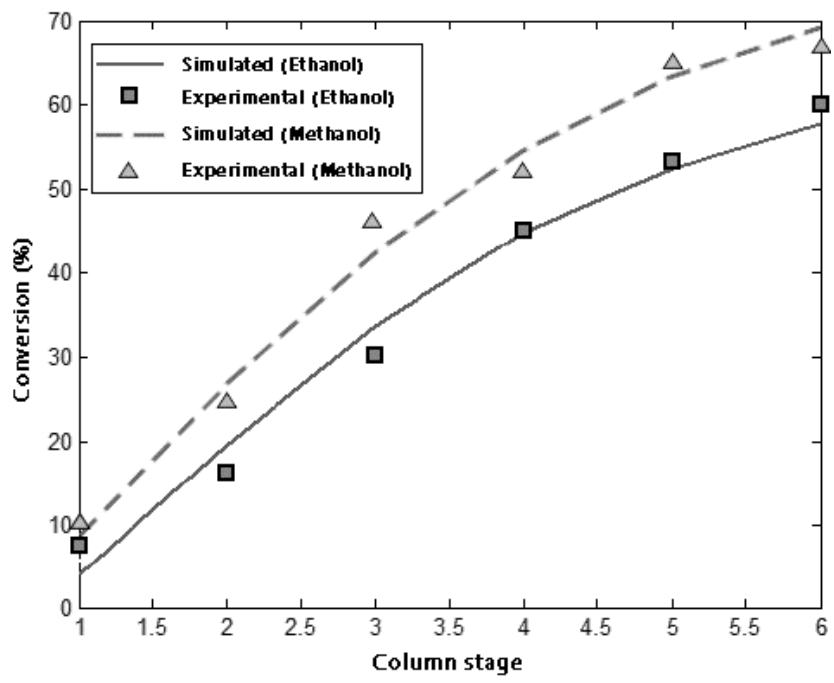

Figure 3. Experimental results compared with simulated ones in ASPEN PLUS based on methylic and ethylic routes.
On the other hand, the experiments based on an ethylic route showed that ester formation at the beggining of the first stages accounted for $7.5 \%$. At the end of the process $60.1 \%$ of ethylic ester was obtained at the bottom of the column. A bi-lateral variance t-Test was also performed in Excel for paired samples as a comparative method in order to show that ester conversion profiles, which were obtained by simulation with a first-order kinetic model, represented adequately the experimental results. The t-Test results are shown in Table 6.

Based on the simulated and experimental results it is possible to observe in Table 6 that the t Statistical value found for the methylic and ethylic routes were 0.374 and 0.483 , respectively. These values are lower than the t-Critical two-tail value of 2.571 , which means that the null hypothesis of no variation can not be rejected at a level of $95 \%$ confidence. Furthemore, the simulated results of the ester conversion profile throughout the column represented adequately the experimental ones for both routes.

The presence of packing along the column contributed to the reaction time and close contact between reactants. The column was $1.5 \mathrm{~m}$ tall with collecting sections in each $0.25 \mathrm{~m}$, accounting for 6 feeding points. Simulated results for 6 stages are close to the experimental results, suggesting a HETP of 0.25 $\mathrm{m}$ for the experimental column, which was obtained by dividing the total height of the column by its number of stages, following standard methodology (McCabe et al., 2005).

After validating the simulated and experimental results a simulation was performed of a 20 stage reactive distillation plant. As a result, it was possible to make a sensitivity analysis in order to study the influence of variables such as reflux and molar ratio for the ethylic and methylic routes. Fig. 4 and Fig. 5

Table 5. Comparison between experimental and simulated results along the reactive distillation column for the biodiesel production process based on the methylic and ethylic routes.

\begin{tabular}{lcccccc}
\hline \multicolumn{1}{c}{ Experimtent } & Stage 1 & Stage 2 & Stage 3 & Stage 4 & Stage 5 & Bottom \\
\hline Ethylic experimental route & $7.5 \%$ & $16.3 \%$ & $30.1 \%$ & $45.2 \%$ & $53.4 \%$ & $60.1 \%$ \\
Simulated ethylic route & $5.6 \%$ & $19.1 \%$ & $33.8 \%$ & $44.9 \%$ & $53.2 \%$ & $58.7 \%$ \\
Methylic experimental route & $10.1 \%$ & $24.3 \%$ & $46.2 \%$ & $52.9 \%$ & $65.1 \%$ & $67.8 \%$ \\
Simulated methylic route & $9.6 \%$ & $26.3 \%$ & $43.4 \%$ & $54.4 \%$ & $64.8 \%$ & $69.6 \%$ \\
\hline
\end{tabular}

Table 6. $\mathrm{t}$-Test for paired two samples based on the ethylic and the methylic routes.

\begin{tabular}{lcccc}
\hline \multirow{2}{*}{ Statistic variable } & \multicolumn{2}{c}{ Ethylic route } & \multicolumn{2}{c}{ Methylic route } \\
\cline { 2 - 5 } & Simulated & Experimental & Simulated & Experimental \\
\hline Mean & 35.883 & 35.433 & 44.683 & 44.400 \\
Variance & 420.974 & 440.287 & 538.074 & 526.408 \\
Observations & 6.000 & 6.000 & 6.000 & 6.000 \\
Pearson Correlation & 0.994 & & 0.997 & \\
Hypothesized Mean Difference & 0.000 & & 0.000 & \\
df & 5.000 & & 5.000 & \\
t-Stat & 0.483 & & 0.374 & \\
t-Critical two-tail & 2.571 & & 2.571 & \\
\hline
\end{tabular}




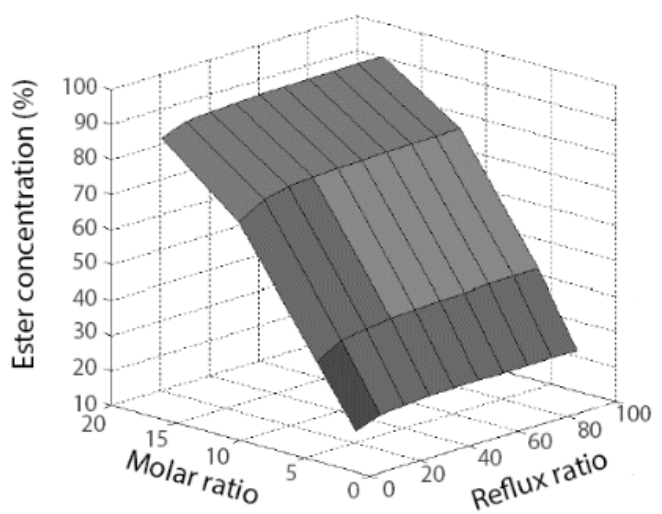

Figure 4. Surface graph for sensitivity analysis based on biodiesel production by the ethylic route.

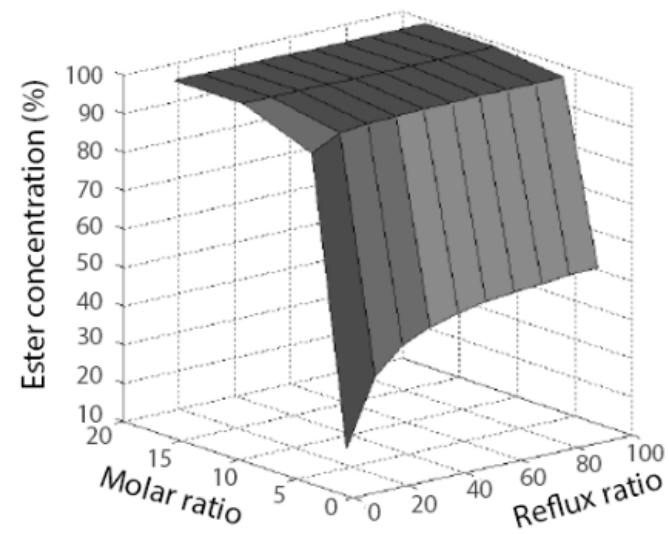

Figure 5. Surface graph for sensitivity analysis based on biodiesel production by the methylic route.

shows surface graphs for sentitivity analysis based on the ethylic and methylic route, respectively.

It can be observed that for molar ratio values under 6/1 (alcohol/oil), the reflux ratio at the top has an influence on methyl ester formation, which is directly proportional to the reflux ratio in this case. However, conversion to methyl ester becomes high for molar ratio values above $6 / 1$ (alcohol/oil). This result is due to the large quantity of alcohol present in the process, which facilitates the oil transesterification reaction. On the other hand, in the case of the simulation for the ethylic route, it can be noted that the alcohol/oil molar ratio has a greater influence than reflux ratio. Even for an alcohol/oil molar ratio 18/1, the response curve for ethylic ester conversion is smoother than the one shown by the methylic route. This result is due to a lower ethylic transesterification reactional velocity compared with the methylic one. Indeed, the reflux ratio increase at the top of the column is associated with higher ester conversions.

It is recommended to operate the column with maximum reflux ratio at the top in order to guarantee complete excess alcohol recovery. Due to a continuous downardly alcohol flow rate inside the column, the volumetric rate of this feeding stream can be reduced during its operation down to the stoichiometric point.
Furthermore, the possibility of operating a biodiesel production process with reactants approaching the stoichiometric ratio shows an industrial competitive advantage compared with the conventional batch process.

The energy assesment is an invaluable requirement to predict the economic viability of a large scale biodiesel production process. Following this, the energy required to carry out biodiesel prodution via the methylic route was compared with the ethylic one. It was intended to monitor the electric power from the reactional step up to the purification stage. Fig. 6 shows an electrical energy comparison between the biodiesel production process via reactive distillation and the batch reactor for the ethylic and methylic routes.

Based on Fig. 6-a, it can be seen that there was a significant power requirement increase for ehtylic biodiesel production via the batch reactor. The total energy of this process amounted to $1210 \mathrm{~W} / \mathrm{h}$ for the methylic route and $2430 \mathrm{~W} / \mathrm{h}$ for the ethylic one. Considering that these two processes are running simultaneously, the transesterification reactions carried out with methanol and ethanol accounted for a percentual energetic cost of $33 \%$ and $67 \%$, respectively,

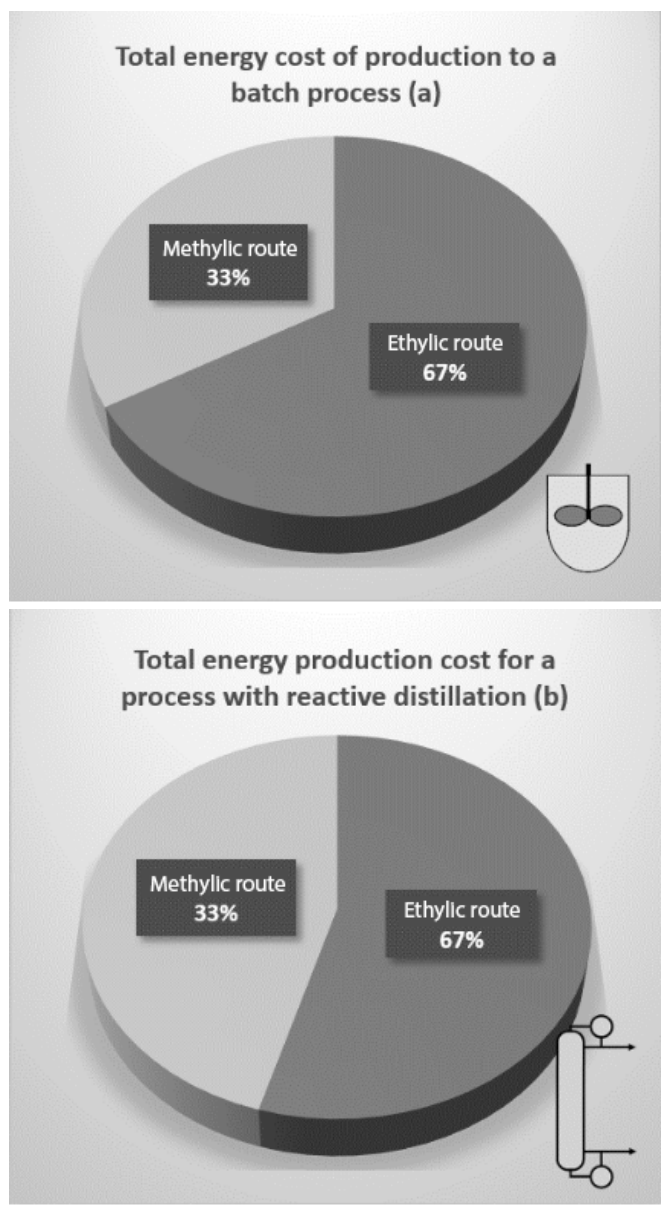

Figure 6. Comparison between energetic demand for ethylic/methylic biodiesel production processes via batch reactors (a) and reactive distillation (b). 
no matter the price of a $\mathrm{kWh}$. Following the same analogy, the energy required to operate only the reactive distillation column comprised $980 \mathrm{~W} / \mathrm{h}$ and $1170 \mathrm{~W} / \mathrm{h}$ for the methylic and ethylic routes, which represented $45 \%$ and $55 \%$ of the energetic cost, respectively, in Fig. 6-b. Although ethanol and methanol have differente latent heats of vaporization, there was no significant energetic discrepancy considering only the column operation with reactional and separation steps. However, the total energy operational cost for ethylic biodiesel production via reactive distillation is almost $10 \%$ higher than the methylic one due to the fact that the subsequent steps of purification to separate ethylic biodiesel and glycerin require more energy (Fig. 6-b).

\section{CONCLUSION}

An ester conversion profile was obtained along the reactive distillation column for the methylic and ethylic routes not only in terms of the simulation study, but also at the experimental level by the reactive distillation technique. Ester formation was verified from the oil feeding point down to the collecting point at the bottom of the column. The reactive distillation operating time of 20 minutes indicated that it is 3 times faster than those with coventional batch reactors.

Experimental and simulated analyses showed that, for a six stage equilibrium column, ethylic biodiesel conversion was $60.1 \%$ and $58.7 \%$, while for methylic production it was $67.8 \%$ and $69.6 \%$, respectively, at the bottom of column. A variance t-Test for paired samples was used as a comparative method for the experimental and simulated results in order to validate both analyses statistically. The t-Statistical values obtained of 0.374 and 0.483 for the methylic and ethylic routes, respectively, were lower than $\mathrm{t}_{(\alpha / 2)}=2.571$. Furthemore, it was possible to represent the analytical results based on the simiulated ones at an $\alpha$ level of 0.05 . Indeed, a HETP of $0.25 \mathrm{~m}$ was suggested for this $1.5 \mathrm{~m}$ tall 6 stage reactive distillation column.

Based on validated results a simulation of sensitivity analysis was carried out for the methylic and ethylic routes in terms of alcoholl/oil molar ratio in the feed stream and reflux ratio at the top of a 20 -stage column. Results showed that it is recommended to operate the column at its maximum reflux ratio in both cases in order to guarantee the total return of alcohol back to the process and to approximate the alcohol/oil molar ratio to the stoichiometric point. A comparison was made between the energy required to operate an ethylic and methylic biodiesel production process via reactive distillation and batch reactors.

The total energy to produce biodiesel via the conventional process was $2430 \mathrm{~W} / \mathrm{h}$ for the ethylic route and $1210 \mathrm{~W} / \mathrm{h}$ for the methylic one. In contrast, there was no significant variation of power required in reactive distillation, considering only column operation to produce ethylic and methylic biodiesel, which amounted to approximately $1000 \mathrm{~W} / \mathrm{h}$. Furthermore, the use of reactive distillation it is suggested for biodiesel production on large scale and especially via the ethylic route.

\section{NOMENCLATURE}

$\begin{array}{ll}\text { CETENE } & \begin{array}{l}\text { Strategic Technologies Center } \\ \text { of Northeast }\end{array} \\ \text { EN 14103 } & \begin{array}{l}\text { European Standard Specifications } \\ \text { Gas Chromatograph }\end{array} \\ \text { GC } & \text { Height equivalent to a Theoretical Plate } \\ \text { HETP } & \text { Non-Random Two-Liquid } \\ \text { NRTL } & \text { Renewable Fuel Standard } \\ \text { RFS } & \text { Universal Functional Activity } \\ \text { UNIFAC } & \text { Coefficient } \\ \text { UNIQUAC } & \text { Universal QuasiChemical } \\ \text { FIT } & \text { Fitting Interpolation Techniques }\end{array}$

\section{ACKNOWLEDGMENTS}

The authors thank the Brazilian Federal Agency for Support and Evaluation of Graduate Education (CAPES) for the financial support and CETENE for providing access to the industrial plant.

\section{REFERENCES}

Aranda, A.G. D, Gonçalves, J. A, Peres, J. S., Ramos A. L. D., Melo, C. A. R. Jr., Antunes, O.A.C., Furtado, N. C., Taft, C. A., The use of acids, niobium oxide, and zeolite catalysts for esterification reactions, Journal of Physical Organic Chemistry, 22(1), 70971 (2009). https://doi.org/10.1002/poc. 1520

Boon-anuwat, N., Kiatkittipong,W.,Aiouache, F and Assabumrungrat, S.,Process design of continuous biodiesel production by reactive distillation: Comparison between homogeneous and heterogeneous catalysts, Chemical Engineering Processing: Process Intensification, 92(1), 33-44 (2015). https://doi.org/10.1016/j.cep.2015.03.025

Chang A., Liu Y.A., Integrated process modeling and product design of biodiesel manufacturing, Journal of Industry and Engineering Chemistry. 49(8), 1197-1213 (2010). https://doi.org/10.1021/ ie 9010047

Choedkiatsakul, I., Ngaosuwanb, K., Cravottoc, G. and Assabumrungrat, S., Biodiesel production from palm oil using combined mechanical stirred and ultrasonic reactor, Ultrasonics Sonochemistry, 21(3), 1585-1591 (2014). https://doi.org/10.1016/j. ultsonch.2013.12.025

Constantinedes A. and Mostoufi N., Numeral Methods for Chemical Engineer witth Matlab Application, $1^{\text {a }}$ Edition, Premtice Hall PTR, New Jersy, 2000. 
Costa, C. C., Guilhoto, J. J. M., Expected growth of sugarcane industry and impact on the Brazilian economy: 2015 and 2020. Munich Personal RePEc Archive. 54001(1), 1-12 (2014).

EN 14103: Fat and oil derivatives - Fatty Acid Methyl Esters (FAME) -Determination of ester and linolenic acid methyl esters content, 2011.

Festel, G.W., Biofuels-economic aspects, chemical engineering \& technology, Chemical Engineering Technolology, 31(5), 715-720 (2008). https://doi. org/10.1002/ceat.200700335

Gmehling, J., Wittig, R., Lohmann, J., Joh, R., A Modified UNIFAC (Dortmund) Model. 4. Revision and Extension, Industrial \& Engineering Chemistry Research, 41(6), 1678-1688 (2002). https://doi. org/10.1021/ie0108043

Gomez-Castro, F. I., Rico-Ramireza, V., SegoviaHernandez, J. G. and Hernandez, S., Feasibility study of a thermally coupled reactive distillation processfor biodiesel production, Chemical Engineering Processing: Process Intensification, 49(3), 262-269 (2010). https://doi.org/10.1016/j.cep.2010.02.002

He B.B., Singh A.P., Thompson J.C., A novel continuous-flow reactor using reactive distillation for biodiesel production, American Society of Biological Engineers, 49(3), 107-112 (4) (2006). https://doi.org/10.13031/2013.20218

Jain, S. K., Kumar, S. and Chaube, A., Technical Sustainability of Biodiesel and its Blends with Diesel in C.I Engines: A Review, International Journal of Chemical Engineering and Applications, 2(3), 101-109 (2012). https://doi.org/10.7763/ IJCEA.2011.V2.84

Kapilakarn K., Peugtong A., A comparison of costs of biodiesel production from transesterication, International Energy Journal, 8(2), 1-6 (2007).

Kiss, A. A, Heat-integrated reactive distillation process for synthesis of fatty esters, Fuel Processing Technology, 92, 1288-1296 (2011). https://doi. org/10.1016/j.fuproc.2011.02.003

Kuramoshi H., Maeda K., Kato S., Osako M., Nakamura K., Sakai S., Application of UNIFAC models for prediction of vapor-liquid equilibria and liquid-liquid equilibria relevant to separation and purification processes of crude biodiesel fuel, Fuel, 88(13), 1472-1477 (2009). https://doi. org/10.1016/j.fuel.2009.01.017

Machado, G. D., Pessoa., F. L. P., Castier, M., Aranda, D. A. G., Cabral, F.V., and CardozoFilho, L., Biodiesel Production by Esterification of Hydrolyzed Soybean Oil with Ethanol in Reactive Distillation Columns: Simulation Studies, Ind. Eng. Chem. Res., 52(27), 9461-9469 (2013). https://doi. org/10.1021/ie400806q

McCabe W.L., Smith J.C., Harriott P., Unit Operations of Chemical Engineering, McGraw Hill, N.Y., 7th Ed. (2005)
Melo, J. C. Pacheco J. G. A., Stragevitch L., Barbosa F. L. P., Jucá J. F., Neves A. M., Cinética da reação de transesterificação do óleo de algodão para produção de biodiesel. Congresso da rede brasileira de tecnologia de biodiesel, 2.,2007,Brasília,DF. Anais...Brasília, DF:MCT/ABIPTI.

Muhammad F., Oliveira M. B., Pignat P., Jaubert J. N., Pinho S. P., Coniglio L., Phase equilibrium data and modeling of ethylic biodiesel, with application to a non-edible vegetable oil, Fuel, 203(1), 633-641 (2017). https://doi.org/10.1016/j.fuel.2017.05.007

Perlingeiro C.A.G., Engenharia de Processos: Análise, Simulação, Otimização e Síntese de Processos Químicos, First ed. Blücher, São Paulo, 2005.

Qian J., Wang F., Liu S., Yun Z., In situ alkaline transesterification of cottonseed oil for production of biodiesel and nontoxic cottonseed meal. Bioresource Technology, 99(18), 9009-9012 (2008). https://doi.org/10.1016/j.biortech.2008.04.059

Rashid U., Anwar F., Knothe G., Evaluation of biodiesel obtained from cottonseed oil, Fuel Process Technology, 90, 1157-1163 (2009). https:// doi.org/10.1016/j.fuproc.2009.05.016

Santana G.C.S., Martins P.F., Silva N. L., Batistella C.B., Maciel F. R., Wolf M. R., Simulation and cost estimate for biodiesel production using castor oil, Chemical Engineering Research and Design, 88(7), 626-663 (2010). https://doi.org/10.1016/j.cherd.2009.09.015

Souza T. P.C., Stragevitch L. Knoechelmann A., J. Pacheco G. A., Silva J.M.F., Simulation and preliminary economic assessment of a biodiesel plant and comparison with reactive distillation, Fuel Process. Technology, 123(6) ,75-81 (2014). https://doi.org/10.1016/j.fuproc.2014.02.004

Vogel A., Mueller-Langer F., Kaltschmitt M., Analysis and evaluation of technical and economic potentials of BtL-fuels, Chemical Engineering Technology, 31(3), 755-764 (2008). https://doi.org/10.1002/ ceat.200800124

Yang, F., Hanna, M. A. and R. Sun., Value-added uses for crude glycerol--a byproduct of biodiesel production. Biotechnology for Biofuels, 5(4), 1-10 (2012). https://doi.org/10.1186/1754-6834-5-13

Yuste A.J., Dorado M.P., Neural network approach to simulate biodiesel production from waste olive oil, Energy Fuel, 20(7), 399-402 (2006). https://doi. org/10.1021/ef050226t

Zhang Y., Dubé M.A., McLean D.D., Kates M., Biodiesel production from waste cooking oil: Economic assessment and sensitivity analysis, Bioresources Technology 90(5), 229-240 (2003). https://doi.org/10.1016/S0960-8524(03)00150-0

Zhang Y., Dubé M.A., McLean D.D., Kates M., Biodiesel production from waste cooking oil: Process design and technology assessment, Bioresources Technology, 99(7), 1131-1140 (2008). 
